\begin{tabular}{l|l|l} 
Jurnal Eksplorasi Akuntansi & $\begin{array}{l}\text { ISSN : 2656-3649 (Online) } \\
\text { hol. 1, No 3, Seri A, Agustus 2019, Hal 826-845://jea.ppj.unp.ac.id/index.php/jea/issue/view/8 }\end{array}$
\end{tabular}

\title{
PENGARUH INDEPENDENSI, KEAHLIAN PROFESIONAL DAN DUKUNGAN MANAJEMEN TERHADAP EFEKTIVITAS FUNGSI AUDIT INTERNAL
}

\author{
Afdel Hamdi', Vita Fitria Sari ${ }^{2}$ \\ 1)Alumni Jurusan Akuntansi Fakultas Ekonomi, Universitas Negeri Padang \\ ${ }^{2)}$ Jurusan Akuntansi Fakultas Ekonomi, Universitas Negeri Padang \\ *Korespondensi: afdelhamdi95@gmail.com
}

\begin{abstract}
Internal audit is the important things in govermant organizationl structures, when the function of internal audit by good configuration, so the internal audit can be important actor in govermant process and institute accountability of sector public. So that, needed talk about the influence factor of efectifity internal audit by independent, profesionality and manajeme support. The purpose of this research is to knowing about the influence of independent, profesionaliti and manajemen support to word internal auditor in govermant in inspectorat sumatera barat province. The result of this research show that independent, profesionality, and manajemen support have possitve influence to word the function of efectifity internal audit in sumatera barat inspectorat
\end{abstract}

Keywords: Independence, professionality, management support, internal audit effectivity

How to cite (APA $6^{\text {th }}$ style)

Hamdi, A., \& Sari, V.F. (2019). Pengaruh Independensi, Keahlian Profesional dan Dukungan Manajemen Terhadap Efektivitas Fungsi Audit Internal. Jurnal Eksplorasi Akuntansi, 1(3), Seri A, 826-845.

\section{PENDAHULUAN}

Upaya dalam mencapai good governance di Indonesia mengalami berbagai kendala, salah satu kendalanya adalah masih tingginya tingkat pelanggaran atau penyalahgunaan wewenang yang dapat dilihat dari banyaknya kasus korupsi, kolusi dan nepotisme $(\mathrm{KKN})$ yang terjadi. KKN ini bahkan telah mendarah daging di hampir seluruh lapisan masyarakat, baik di sektor publik maupun swasta dan sering pula terjadi di kedua sektor tersebut secara bersamaan (Prayudiawan, 2011).

Korupsi, kolusi dan nepotisme ini menjadi salah satu permasalahan yang merugikan negara maupun masyarakat karena berdampak terhadap kualitas infrastruktur yang lemah dan pelayanan publik, timbulnya ekonomi biaya tinggi, berkurangnya pendapatan negara/pemerintahan daerah, runtuhnya lembaga dan nilai-nilai demokrasi. Faktor di atas dapat membahayakan kelangsungan pembangunan dan supremasi hukum internal yang merupakan 
bagian internal pemerintah yang mengawasi jalannya pemerintahan. Agar dampak tersebut dapat diminimalisir maka sangat perlu dilakukan audit internal pada setiap instansi pemerintah.

Audit internal adalah bagian penting dari struktur organisasi pemerintah (Coram, Ferguson, dan Moroney, 2008), jika fungsi audit internal dijalankan dengan konfigurasi yang baik, maka audit internal dapat memainkan peran penting dalam proses pemerintahan dan akuntabilitas lembaga-lembaga sektor publik melalui penilaian mereka pada efektivitas pengendalian organisasi kunci, tata kelola dan proses manajemen risiko (Asare, 2009). Audit internal dan praktiknya dapat menjadikan profesi auditor dalam manajemen risiko, pengendalian dan proses tata kelola pada level strategis dan operasional (D'Silva dan Ridley, 2007). Sarens dan Beelde (2006) menyebutkan empat dimensi dari audit internal yaitu evaluasi, diagnosis, memberi informasi, dan memberi rekomendasi.

Audit internal berperan untuk mengevaluasi, melaporkan pendapatnya berkaitan dengan kelemahan yang ada pada proses yang berjalan dan pengendalian internal, kemudian memberikan saran yang mungkin dapat meningkatkan kinerja auditan. Sarens dan Beelde (2006) menyebutkan manajemen senior di Belgia mengharapkan audit internal melengkapi perannya untuk mendukung manajemen, meliputi monitoring dan peningkatan manajemen risiko dan pengendalian internal, serta memantau budaya organisasi.

Audit internal pemerintahan Indonesia telah memiliki standar sendiri, yaitu Standar Audit Intern Pemerintah Indonesia yang dituangkan dalam Keputusan Nomor: KEP005/AAIPI/DPN/2014 tanggal 24 April 2014 tentang Pemberlakuan Kode Etik Auditor Intern Pemerintah Indonesia, Standar Audit Intern Pemerintah Indonesia, dan Pedoman Telaah Sejawat Auditor Intern Pemerintah Indonesia Dewan Pengurus Nasional (DPN), Asosiasi Auditor Intern Pemerintah Indonesia (AAIPI). APIP merupakan aparat pemerintah yang bertugas melaksanakan pengawasan intern di lingkungan pemerintah pusat dan/atau pemerintah daerah, yang terdiri dari Badan Pengawasan Keuangan dan Pembangunan (BPKP), Inspektorat Jenderal/Inspektorat/Unit Pengawasan Internal pada Kementerian/ Kementerian Negara, Inspektorat Utama/Inspektorat Lembaga Pemerintah Non Kementerian, Inspektorat/Unit Pengawasan Internal pada Kesekretariatan Lembaga Tinggi Negara dan Lembaga Negara, Inspektorat Provinsi/Kabupaten/Kota, dan Unit Pengawasan Internal pada Badan Hukum Pemerintah lainnya sesuai dengan peraturan perundang-undangan.

Peraturan Pemerintah No. 60 tahun 2008 tentang Sistem Pengendalian Internal Pemerintah pasal 2 ayat (1) menyatakan bahwa untuk mencapai pengelolaan keuangan negara yang efektif, efisien, transparan, dan akuntabel, pimpinan instansi pemerintah wajib melakukan pengendalian atas penyelenggaraan kegiatan pemerintahan, yang disebut dengan Sistem Pengendalian Internal Pemerintah (SPIP). Sehingga dapat disimpulkan bahwa peran aparat pengawasan intern pemerintah yang efektif penting dalam mewujudkan pengelolaan keuangan negara yang efisien, efektif, transparan, dan akuntabel.

Data penanganan korupsi tahun 2012-2016 yang disajikan oleh Komisi Pemberantasan Korupsi (KPK) dalam website http://acch.kpk.go.id menunjukan masih banyaknya kasus korupsi di Indonesia. Berdasarkan data tersebut, Kementerian/Lembaga menempati posisi teratas dalam hal jumlah kasus korupsi yang ditangani KPK dengan 119 kasus, disusul oleh pemerintah kabupaten/kota sebanyak 57 kasus, serta pemerintah provinsi sebanyak 46 kasus. Data tersebut menarik untuk dikaji, sebab dalam tiga kelompok instansi tersebut terdapat APIP seperti yang diamanatkan oleh standar audit intern dan peraturan pemerintah No. 60 tahun 2008. Apabila standar audit internal AAIPI, maka salah satu peran APIP adalah anticorruption activities, yaitu memberikan peringatan dini terhadap kemungkinan adanya penyimpangan (fraud). Fakta 
tersebut mengindikasikan adanya permasalahan efektivitas APIP dalam menjalankan fungsinya sebagai aparat pengawas pemerintah, efektivitas APIP dalam menjalankan fungsi pengawasan intern pemerintah menjadi penting untuk dikaji.

Penelitian tentang audit internal sudah banyak dilakukan diinstansi pemerintahan. Salah satu penelitian audit internal pernah dilakukan oleh Anto, dkk (2016), penelitian tersebut membahas tentang faktor-faktor yang berpengaruh terhadap efektivitas audit internal pemerintah di Indonesia yang dilakukan di BPKP 33 provinsi Indonesia. Hasil penelitian tersebut menunjukan bahwa keahlian profesional, kualitas pekerjaan audit, independensi organisasi, karir dan penjenjangan, serta dukungan pimpinan entitas faktor penting dalam pencapaian efektivitas internal audit di pemerintahan.

Beberapa peneliti juga telah mengkaji faktor penentu efektivitas audit internal, diantaranya adalah keahlian profesional auditor berupa kualifikasi auditor, pengembangan dan pelatihan (Al-Twaijry, Brierley, dan Gwilliam, 2003; Mihret dan Yismaw, 2007; dan Arena dan Azzone, 2009). Faktor lainnya adalah karir dan penjenjangan (Goodwin dan Yeo, 2001; Cohen dan Sayag, 2010), dukungan manajemen (Mihret dan Yismaw, 2007; dan Cohen dan Sayag, 2010), keadaan organisasi berupa status dan kebijakan serta prosedurnya (Mihret dan Yismaw, 2007), hubungan organisasi berupa antara internal audit dan komite audit (Arena dan Azzone, 2009), serta independensi dari auditor (Cohen, 2010). Setiap faktor-faktor tersebut memiliki pengaruh tersendiri terhadap pencapaian efektivitas fungsi audit internal. Akan tetapi, belum ada penelitian yang dilakukan tentang pengaruh independensi, keahlian profesional dan dukungan manajemen terhadap efektivitas fungsi audit internal.

Selain itu, penelitian tentang efektivitas audit internal pemerintah di Indonesia baru pernah dilakukan di BPKP, Anto dkk (2016). Sementara itu, penelitian ini akan dilaksanakan di inspektorat, karena sebelumnya belum ada peneliti yang melakukan penelitian audit internal di inspektorat dan juga pada inspektorat audit internal berada di dalam organisasi sebagai pengawas, sehingga auditor internal memiliki keleluasaan untuk memantau semua aktivitas yang terjadi dalam organisasi tersebut. Hasil penelitian yang dilakukan Alzeban (2014), dan Cohen (2010) menunjukan bahwa efektivitas audit internal dipengaruhi oleh independensi dan dukungan manajemen. Tri (2016) menyatakan bahwa keahlian professional juga berpengaruh terhadap efektivitas audit internal. Sedangkan penelitian yang dilakukan Naufal (2015) menunjukan bahwa keahlian profesional, independensi dan dukungan manajemen tidak berpengaruh terhadap efektivitas audit internal. Berdasarkan perbedaan hasil penelitian yang dilakukan oleh para peneliti terdahulu maka perlu dilakukan penelitian dan pengkajian ulang terkait faktor yang mempengaruhi efektivitas audit internal sedingga dapat memberikan pandangan lain.

Berdasarkan pemaparan di atas maka peneliti akan melakukan penelitian tentang "Pengaruh independensi, keahlian profesional dan dukungan manajemen terhadap efektivitas fungsi audit internal".

\section{REVIU LITERATUR DAN PENGEMBANGAN HIPOTESIS Efektivitas Audit Internal}

Arens et al. (2008) mendefinisikan efektivitas sebagai berikut, efektivitas merujuk ke pencapaian tujuan, sedangkan efisiensi mengacu ke sumber daya yang digunakan untuk mencapai tujuan tersebut. Menurut Handoko (2001) efektivitas merupakan kemampuan untuk memilih tujuan yang tepat untuk mencapai tujuan yang telah ditetapkan. Sama halnya dengan pengertian yang 
diungkapkan oleh Handayaningrat (2002) efektivitas ialah pengukuran dalam arti tercapainya sasaran, yaitu tujuan yang telah ditentukan sebelumnya.

Berdasarkan definisi diatas, dapat disimpulkan bahwa efektivitas lebih menitikberatkan pada tingkat keberhasilan organisasi dalam mencapai tujuan yang telah ditetapkan. Jadi, penilaian efektivitas didasarkan atas sejauh mana tujuan organisasi dapat dicapai dan pencapaian sasaran yang berkaitan dengan tujuan yang telah ditetapkan. Audit internal merupakan pengawasan manajerial yang fungsinya mengukur dan mengevaluasi sistem pengendalian dengan tujuanmembantu semua anggota manajemen dalam mengelola secara efektif pertanggungjawabannya dengan cara menyediakan analisis, penilaian, rekomendasi, dan komentar-komentar yang berhubungan dengan kegiatan-kegiatan yang ditelaah (Sawsan, 2015).

Agoes (2004) berpendapat bahwa audit internal adalah pemeriksaan yang dilakukan oleh bagian internal audit perusahaan, baik terhadap laporan keuangan dan catatan akuntansi perusahaan, maupun ketaatan terhadap kebijakan manejemen puncak yang telah ditentukan dan ketaatan terhadap peraturan pemerintah dan ketentuan-ketentuan dari ikatan profesi yang berlaku. Internal auditing atau pemeriksaan internal adalah suatu fungsi penilaianindependen dalam organisasi dengan tujuan untuk menguji dan mengevaluasi kegiatan-kegiatan organisasi yang dilaksanakan (Arens, 2014). Kesimpulannya audit internal merupakan bagian atau proses pemeriksaan dan pengawasan yang dilakukan oleh auditor internal yang bertujuan untuk memastikan bahwa kegiatan-kegiatan pencapaian tujuan akan tercapai dengan baik.

Bila dikaitkan dengan efektivitas, maka efektivitas audit internal merupakan kemampuan auditor internal untuk mencapai atau mewujudkan fungsi dari audit internal. Terkait dengan hal tersebut, Inspektorat Provinsi Sumatera Barat selaku auditor internal di tingkat provinsi memiliki kewajiban dan tanggung jawab untuk dapat mewujudkan dan mencapai tujuan dan fungsi dari efektivitas audit internal itu sendiri melalui program-program dan fasilitasi pengawasan yang telah direncanakan.

Audit internal merupakan "mata dan telinga" bagi manajemen di suatu organisasi untuk memastikan bahwa program-program kerja dalam rangka pencapaian tujuan organisasi tidak dilakukan secara menyimpang (Tampubolon, 2005). Terkait dengan fungsi tersebut audit internal diharapkan mampu memberikan perbaikan efisiensi dan efektivitas dalam rangka peningkatan kinerja organisasi. Pelaksanaan audit internal untuk memberikan pelayanan kepada organisasi, dalam rangka membantu semua anggota organisasi tersebu (Moroney, 2008). Bantuan yang diberikan sebagai tujuan akhir adalah agar semua anggota organisasi dapat melaksanakan tanggung jawab yang dibebankan kepadanya secara efektif atau lebih jauh lagi mencapai efektivitas optimal. Untuk hal tersebut, auditor internal akan memberikan berbagai analisis, penilaian, rekomendasi, petunjuk dan informasi sehubungan dengan kegiatan yang diperiksa.

Ritley (2007) menyatakan ruang lingkup audit internal yaitu menilai keefektifan sistem pengendalian internal, pengevaluasian terhadap kelengkapan dan keefektifan sistem pengendalian internal yang dimiliki organisasi, serta kualitas pelaksanaan tanggung jawab yang diberikan yang berguna untuk pencapaian tujuan suatu organisasi. Adapun aspek efektivitas audit internal yang diteliti dalam penelitian ini berkaitan dengan kualitas audit, evaluasi auditan dan kontribusi tambahan yang diberikan oleh audit internal terhadap manajemen.

\section{Independensi}

Profesi auditor harus bersifat independen dan berkomitmen secara eksplisit dalam melayani kepentingan publik. Pada pemerintah yang bertujuan di bidang pubic service adalah pegawai profesional agar dapat bertanggung jawab pada publik, para auditor harus berupaya untuk 
meningkatkan kemampuan atau kinerja dalam menjalankan profesinya (Carolita dan Rahardjo, 2012). Menurut Badjuri (2011) independensi secara umum mencakup dua aspek, yaitu independensi dalam fakta (in fact) dan independensi dalam penampilan (in apperance). Independensi in fact merupakan kemampuan auditor untuk bersikap bebas, jujur, dan objektif dalam penugasan audit. Sedangkan independensi inapperance adalah independensi yang dipandang dari pihak-pihak yang berkepentingan terhadap perusahaan yang di audit yang mengetahui hubungan antara auditor dengan kliennya. Auditor akan dianggap tidak independen apabila auditor tersebut mempunyai hubungan tertentu (hubungan keluarga atau hubungankeuangan) dengan kliennya yang dapat menimbulkan kecurigaan bahwa auditor berlaku tidak independen (Thomas, 2009). Independensi merupakan sikap yang tidak mudah dipengaruhi, dan tidak memihak pada pihak-pihak tertentu.

Auditor tidak dibenarkan memihak kepentingan pihak- pihak tertentu. Auditor berkewajiban untuk jujur tidak hanya kepada diri sendiri tetapi juga kepada orang lain. Seorang auditor harus memiliki prinsip- prinsip etika yang di antaranya adalah kompetensi, independensi, dan akuntabilitas (Ardini, 2010). Penilaian masyarakat atas independensi auditor bukan pada diri auditor secara keseluruhan. Namun, apabila seorang auditor lalai atau gagal mempertahankan sikap independensinya, maka kemungkinan besar masyarakat memiliki anggapan bahwa semua auditor internal pemerintah tidak independen. Kecurigaan tersebut dapat berakibat berkurang atau hilangnya kredibilitas masyarakat terhadap jasa audit profesi auditor independen (Mulyadi, 2012).

Menurut Scott et al (2000) dalam Meutia (2004) auditor independen seharusnya dapat menjadi pelindung terhadap praktek-praktek akuntansi, karena auditor tidak hanya dianggap memiliki pengetahuan yang mendalam di bidang akuntansi tetapi juga dapat berhubungan dengan komite audit dan dewan direksi yang bertanggung jawab untuk memeriksa dengan teliti para pembuat keputusan di perusahaan. Aspek independensi yang diteliti pada penelitian ini berkaitan dengan hubungan kerja didalam entitas internal audit, hubungan kerja antar sesama auditor dan hubungan kerja auditor dengan manajemen.

\section{Keahlian Profesional}

Keahlian merupakan keterampilan dari seorang ahli. Ahli didefinisikan sebagai seseorang yang memiliki tingkat keterampilan tertentu atau pengetahuan yang tinggi dalam subjek tertentu yang diperoleh dari pelatihan atau pengalaman. Dalam artikel yang sama Roth dkk (1983) dalam Desyanti (2006) mendefinisikan keahlian sebagai keberadaan dari pengetahuan tentang suatu lingkungan tertentu, pemahaman terhadap masalah-masalah yang timbul dalam lingkungan tersebut, dan keterampilan untuk memecahkan permasalahan tersebut.

Profesionalisme telah menjadi isu yang kritis untuk profesi audit internal karena dapat menggambarkan kinerja auditor internal tersebut. Gambaran terhadap profesionalisme dalam profesi auditor internal seperti yang dikemukakan oleh Hastuti et al. (2003) dicerminkan melalui lima dimensi, yaitu pengabdian pada profesi, kewajiban sosial, kemandirian, keyakinan terhadap profesi dan hubungan dengan rekan seprofesi.Selain menjadi seorang profesional yang memiliki sikap profesionalisme, auditor internal juga harus memiliki pengetahuan yang memadai dalam profesinya untuk mendukung pekerjaannya dalam melakukan setiap pemeriksaan (Herawaty dan Susanto,2008).

Secara umum, seseorang dikatakan profesional jika memenuhi tiga kriteria, yaitu mempunyai keahlian untuk melaksanakan tugas sesuai dengan bidangnya, melaksanakan suatu tugas atau profesi dengan menetapkan standar baku di bidang profesi yang 
bersangkutan dan menjalankan tugas profesinya dengan mematuhi etika profesi yang telah ditetapkan.

Profesi dan profesionalisme dapat dibedakan secara konseptual seperti dikemukakan oleh Lekatompessy (2003). Profesi merupakan jenis pekerjaan yang memenuhi beberapa kriteria, sedangkan profesionalisme merupakan suatu atribut individual yang penting tanpa melihat apakah suatu pekerjaan merupakan suatu profesi atau tidak. Seorang auditor internal yang profesional harus memenuhi tanggung jawabnya terhadap masyarakat, klien termasuk rekan seprofesi untuk berperilaku semestinya.

Kepercayaan masyarakat terhadap kualitas jasa audit profesional meningkat jika profesi menetapkan standar kerja dan perilaku yang dapat mengimplementasikan praktik bisnis yang efektif dan tetap mengupayakan profesionalisme yang tinggi (Jusuf1997) dalam HerawatydanSusanto (2008). Aspek profesional yang diteliti dalam penelitian ini berkaitan dengan pendidikan dan pelatihan yang diikuti oleh auditor untuk menunjang profesionalisme auditor dalam menjalankan tugasnya, penmahaman auditor terhadap prosedur pelaksanaan audit internal, serta pengalaman yang dimiliki auditor dalam menlaksanakan audit internal.

\section{Dukungan Manajemen}

Mihret dan Yismaw (2007) menyatakan bahwa management support merupakan salah satu faktor penting disamping kualitas audit internal guna mewujudkan efektivitas audit internal. Seorang auditor internal bekerja tidak sendirian. Auditor internal bekerja secara tim dalam suatu organisasi (Cohen, 2010). Pelaksanaan audit internal tidak akan berjalan dengan baik tanpa adanya dukungan dari pimpinan entitas, baik dalam wujud anggaran yang cukup serta sarana prasarana yang memadai (Anto,2016). Selain itu dukungan juga dapat berupa kenyamanan secara fisik dan mental bagi para auditor internal, sehingga dalam menjalankan tugasnya mereka tidak akan terbebani dengan hal-hal di luar lingkup penugasannya.

Auditor memiliki tanggung jawab penuh dalam melaksanakan tugas pemeriksaan internal, untuk itu dibutuhkan independensi dan keahlian profesional yang cukup agar dapat melaksanakan tugasnya dengan baik (Kasdiarto, 2015). Pemeriksaan internal merupakan kegiatan yang penting untuk menilai sejauh mana kebijakan yang ditetapkan pemerintah telah terlaksana dengan tepat, dan apabila terdapat penyimpangan pengawas internal harus segera melakukan tindakan koreksi agar program pemerintah dapat tercapai dengan baik.

Adanya dukungan tersebut, auditor akan dapat menjalankan tugasnya dengan baik, sehingga dapat menghasilkan rekomendasi yang tepat dan dapat memberikan nilai tambah bagi auditan. Dukungan manajemen puncak memiliki pengaruh yang signifikan terhadap efektivitas audit internal (Cohen, 2010). Hal ini didukung oleh Mihret et al. (2010) dengan menambahkan dukungan manajemen berupa alokasi sumber daya manusia dan material yang memadai berpengaruh terhadap efektivitas audit internal.

Menurut Tugiman (2006) dukungan manajemen puncak dapat ditunjukan dengan adanya sikap untuk memberikan masukan dan motivasi terhadap pelaksanaan audit internal. Ketika pelaksanaan audit internal telah didukung oleh manajemen puncak maka tujuan dan sasaran yang ingin diperoleh akan tercapai. Sinergi yang terjadi antara pimpinan dengan pegawai pengawas internal dapat meningkatkan kinerja dari pengawas internal dalam melaksanakan tugasnya (Marta, 2014). Praktik pembinaan dan pengawasan oleh Inspektorat Provinsi terhadap peningkatan kinerja Satuan Kerja Perangkat Daerah (SKPD) di Provinsi. Kepala SKPD provinsi dan kabupaten/kota diwajibkan melaksanakan tindak lanjut hasil pengawasan paling lambat 60 
hari kalender setelah diterimanya laporan hasil pengawasan. Di Provinsi Sumatera barat selain Kepala SKPD provinsi dan kabupaten/kota yang diwajibkan melaksanakan tindak lanjut hasil pengawasan, wakil gubernur dan wakil bupati/walikota juga bertanggung jawab atas pelaksanaan tindak lanjut hasil pengawasan tersebut. Hal ini tertuang dalam pasal 6 Peraturan Gubernur Sumatera Barat Nomor 77 Tahun 2016.

\section{Hipotesis Penelitian}

Hipotesis yang akan diuji dalam penelitian ini adalah sebagai berikut:

H1 : Independensi berpengaruh signifikan positif terhadap efektivitas audit internal.

$\mathrm{H} 2$ : Keahlian profesional berpengaruh signifikan positif terhadap efektivitas fungsi audit Internal.

H3 : Dukungan manajemen berpengaruh signifikan positif terhadap efektivitas fungsi audit internal.

\section{METODE PENELITIAN}

Penelitian ini merupakan penelitian kausatif dengan populasi dan sampel yaitu seluruh auditor internal Inspektorat Pemerintah Daerah Provinsi Sumatera Barat. Jenis data dalam penelitian ini digolongkan pada data subjek (self report data) yang dikumpulkan melalui penelitian pustaka dan penelitian lapangan dengan menggunakan kuesioner. Data yang diperoleh akan dianalisis melalui analisis deskripsi, uji asumsi klasik dan uji hipotesis. Analisis deskripsi terdiri dari verifikasi data yang diperoleh, menghitung nilai jawaban, menghitung rata-rata skor total item, menghitung nilai rerata jawaban responden, menghitung nilai TCR masing-masing kategori jawaban dari deskriptif variabel. Sementara itu, uji asumsi klasik terdiri dari uji normalitas, uji heterokedastisitas dan uji multikolinearitas, sedangkan uji hipotesis terdiri dari uji kooefisien dterminasi yang disesuaikan (adjusted $R^{2}$ ), analisis regresi berganda, uji $\mathrm{F}$ (F-Test), dan uji hipotesis ( $t$-Test).

Pada penelitian ini agar tidak terjadi kesalah pahaman terhadap variabel-variabel yang digunakan, maka perlu diberikan definisi operasional pada penelitian ini adalah (1) efektivitas fungsi audit internal merupakan suatu keefektifan audit yang dilakukan oleh auditor dalam melakukan suatu pemeriksaan kinerja pemerintah, dimana hasil dari pemeriksaan tersebut dapat dijadikan sebagai rekomendai kepada pihak tertentu, (2) independensi merupakan sikap netral atau kesadaran yang dimiliki oleh seorang auditor dalam melaksanakan tugasnya untuk memeriksa kinerja pemerintah, (3) keahlian profesional adalah kecakapan atau kemampuan atau keahlianyang dimiliki seorang auditor dalam melakukan tugasnya untukmemeriksa kinerja pemerintah, (4) dukungan manajemen merupakan adanya dorongan dan partisipasi yang diberikan manajemen kepada auditor yang dapat mendukung auditor dalam melaksanakan tugasnya.

\section{HASIL DAN PEMBAHASAN \\ Profil Responden}

Kedudukan inspektorat provinsi Sumatera Barat merupakan aparat pengawas fungsional yang berada dibawah dan bertanggung jawab kepada Gubernur Sumatera Barat, dan bertugas melakukan pengawasan terhadap pelaksanaan urusan pemerintahan di daerah provinsi, pelaksanaan pembinaan atas penyelenggaraan pemerintah daerah kabupaten/kota dan pelaksanaan urusan pemerintahan di daerah kabupaten/kota. Pengawasan atas penyelenggaraan pemerintah daerah merupakan proses kegiatan yang ditujukan untuk menjamin agar pemerintah 
daerah berjalan secara efektif dan efisien sesuai rencana dan ketentuan peraturan perundangundangan. Sesuai peraturan pemerintah No 41 tahun 2007, inspektorat sebagai perangkat daerah dibawah gubernur yang mempunyai mandate untuk melakukan pengawasan fungsional atas kinerja organisasi pemerintah daerah. Sehingga dalam tugasnya inspektorat sama halnya dengan auditor internal dalam sebuah perusahaan dalam mencegah dan menanggulangi terjadinya kecurangan atau KKN.

Salah satu unit yang melakukan audit/pemeriksaan terhadap pemerintah daerah adalah inspektorat. Adapun tugas pokok inspektorat adalah: (a) Inspektorat merupakan unsur penunjang pemerintah, dipimpin oleh seorang inspektur yang berkedudukan dibawah dan bertanggung jawab kepada kepala daerah melalui sekretaris daerah, (b) Inspektorat mempunyai tugas membantu kepala daerah dalam bidang pengawasan.

Inspektorat provinsi Sumatera Barat selaku aparat pengawas intern pemerintah provinsi Sumatera Baratmempunyai fungsi, yaitu: (a) Perencanaan program pengawasan, (b) Perumusan kebijakan dan fasilitas pengawasan, (c) Pemeriksaan, pengusutan, pengujian, dan penilaiaan tugas pengawasan.

\section{Demografi Responden (Gambaran Umum Responden)}

Data dalam penelitian dikumpulkan dengan menyebarkan kuesioner secara langsung kepada auditor internal inspektorat provinsi Sumatera Barat. Penyebaran kuesioner dilakukan kurang lebih 2 minggu. Kuesioner dibagikan dengan cara mendatangi secara langsung ke kantor inspektorat provinsi Sumatera Barat. Kuesioner yang disebar sebanyak 35 kuesioner, dari keseluruhan kuesioner 1 kuesioner yang tidak kembali. Jadi total kuesioner yang digunakan sebagai bahan analisis adalah 34 kuesioner. Rincian responden penelitian dapat dilihat pada tabel 1 berikut.

Tabel 1.

Penyebaran dan Pengembalian kuesioner

\begin{tabular}{|l|c|}
\hline \multicolumn{1}{|c|}{ Keterangan } & Jumlah \\
\hline Jumlah Kuesioner yang disebar & 35 \\
\hline Jumlah kuesioner yang kembali & 34 \\
\hline Respon Rate & $\mathbf{9 7 , 1 4 \%}$ \\
\hline
\end{tabular}

Berdasarkan tabel di atas, terlihat bahwa respon rate responden yang mengisi dan yang mengembalikan kuesioner adalah 97,14\% kuesioner diantar dan dijemput langsung kepada respon penelitian.

\section{Statistik Deskriptif}

Statistik deskriptif dalam penelitian ini disajikan untuk memberikan gambaran tentang karakteristik variabel penelitian, diantaranya nilai minimum, maximum, mean, dan standar deviasi. Nilai minimum merupakan nilai terendah dari suatu distribusi data. Pengukuran ratarata (mean) merupakan cara yang paling umum digunakan untuk mengukur nilai interval dari suatu distribusi data, rata-rata hitung (mean) dari sekelompok atau serangkaian data adalah jumlah dari seluruhnilai data dibagi dengan banyak data. Standar deviasi merupakan perbedaan data yang diteliti dengan rata-rata hitung sekelompok data tersebut. Adapun jumlah sampel yang digunakan dalam penelitian ini adalah sebanyak 34 orang dari 35 auditor dan pengawas pemerintah di inpektorat provinsi Sumatera Barat . Adapun variabel independensi memiliki rata- 
rata sebesar 4,11 dengan standar devisiasi 0,503, variabel keahlian professional memiliki ratarata sebesar 4,15 dengan standar devisiasi 0,303, dan variabel dukungan manajemen diketahui memiliki rata-rata 4,13 dengan standar devisiasi 0,364. Sedangkan untuk variabel efektifitas fungsi audit internal diketahui memiliki rata-rata 3,71 dengan standar devisiasi 0,503.

\section{Deskriptif Hasil Penelitian}

Deskripsi hasil penelitian merupakan deskripsi dari hasil penelitian tentang efektifitas fungsi audit internal pada auditor internal di inspektorat provinsi Sumatera Barat. Variabel-Variabel tersebut dapat dikategorikan berdasarkan:

\section{a) Efektifitas fungsi audit internal}

Variabel efektifitas fungsi audit internal yang diteliti dalam penelitian ini berkaitan dengan kualitas audit, evaluasi auditan, dan kontribusi tambahan yang diberikan oleh audit internal terhadap manajemen. Aspek penilitan tersebut tersebar dalam 36 item pernyataan pada kuesioner, dapat dilihat pada tabel 2 . berikut.

\section{Tabel 2.}

Distribusi Frekuensi Variabel Efektifitas Fungsi Audit Internal

\begin{tabular}{|c|c|c|c|c|}
\hline No & Item Pernyataan & Rerata & $\begin{array}{l}\text { TCR } \\
(\%)\end{array}$ & Kategori \\
\hline 1 & $\begin{array}{l}\text { Entitas Internal audit memberikan informasi tentang } \\
\text { permasalahan dalam pelaksanaan operasional dan } \\
\text { sistem pengendalian di Kementerian/Lembaga/ } \\
\text { Pemerintah Daerah. }\end{array}$ & 4,03 & 80,6 & $\begin{array}{l}\text { Sangat } \\
\text { Baik }\end{array}$ \\
\hline 2 & $\begin{array}{l}\text { Tugas dan aktivitas yang saudara terima dari instansi } \\
\text { sesuai dengan ekspektasi yang saudara miliki. }\end{array}$ & 4,06 & 81,2 & $\begin{array}{l}\text { Sangat } \\
\text { Baik }\end{array}$ \\
\hline 3 & $\begin{array}{l}\text { Pelaksanaan audit internal, didalamnya mencakup } \\
\text { isu-isu yang berkaitan dengan ekonomis, efisiensi, } \\
\text { dan efektivitas. }\end{array}$ & 4,29 & 85,9 & $\begin{array}{l}\text { Sangat } \\
\text { Baik }\end{array}$ \\
\hline 4 & $\begin{array}{l}\text { Entitas internal audit menyadari dan peka terhadap } \\
\text { kebutuhan Kementerian/Lembaga/ Pemerintah } \\
\text { Daerah dan mampu memenuhi kebutuhan tersebut } \\
\text { secara tepat. }\end{array}$ & 3,85 & 77,1 & Baik \\
\hline 5 & $\begin{array}{l}\text { Evaluasi laporan hasil audit internal oleh ketua tim } \\
\text { audit dilaksanakan secara cukup dan memadai. }\end{array}$ & 4,06 & 81,2 & $\begin{array}{l}\text { Sangat } \\
\text { Baik }\end{array}$ \\
\hline 6 & $\begin{array}{l}\text { Evaluasi laporan hasil audit internal oleh supervisor } \\
\text { audit dilaksanakan secara cukup dan memadai. }\end{array}$ & 3,91 & 78,2 & Baik \\
\hline 7 & $\begin{array}{l}\text { Evaluasi laporan hasil audit internal oleh } \\
\text { penanggungjawab audit dilaksanakan secara cukup } \\
\text { dan memadai. }\end{array}$ & 4,06 & 81,2 & $\begin{array}{l}\text { Sangat } \\
\text { Baik }\end{array}$ \\
\hline 8 & $\begin{array}{l}\text { Entitas internal audit mengidentifikasi risiko dan } \\
\text { mengevaluasi sistem pengendalian secara memadai, } \\
\text { sehingga menjadi "penjaga gawang" bagi } \\
\text { Kementerian/Lembaga/Pemerintah Daerah. }\end{array}$ & 4,09 & 81,8 & $\begin{array}{l}\text { Sangat } \\
\text { Baik }\end{array}$ \\
\hline 9 & $\begin{array}{l}\text { Pimpinan instansi berkomitmen dan fokus pada isu- } \\
\text { isu yang diaudit oleh auditor internal. }\end{array}$ & 3,68 & 73,5 & Baik \\
\hline 10 & Permasalahan yang akan diaudit diputuskan setelah & 4,12 & 82,4 & Sangat \\
\hline
\end{tabular}




\begin{tabular}{|c|c|c|c|c|}
\hline No & Item Pernyataan & Rerata & $\begin{array}{l}\text { TCR } \\
(\%)\end{array}$ & Kategori \\
\hline & $\begin{array}{l}\text { mengidentifikasi, mengukur dan menentukan tingkat } \\
\text { risiko yang akurat. }\end{array}$ & & & Baik \\
\hline 11 & $\begin{array}{l}\text { Semua aktivitas pengendalian dan audit internal di } \\
\text { Kementerian/Lembaga/Pemerintah } \\
\text { dilakukan oleh entitas internal audit atau } \\
\text { dikoordinasikan antara internal audit dengan } \\
\text { eksternal audit. }\end{array}$ & 4,20 & 85,0 & $\begin{array}{l}\text { Sangat } \\
\text { Baik }\end{array}$ \\
\hline 12 & $\begin{array}{l}\text { Entitas internal audit adalah unit organisasi otonom } \\
\text { dan mandiri. }\end{array}$ & 4,29 & 85,9 & $\begin{array}{l}\text { Sangat } \\
\text { Baik }\end{array}$ \\
\hline 13 & $\begin{array}{l}\text { Entitas dan personil internal audit memiliki } \\
\text { kompetensi yang handal dan berintegritas tinggi. }\end{array}$ & 3,79 & 75,9 & Baik \\
\hline 14 & $\begin{array}{l}\text { Entitas internal audit bernilai dan berkontribusi bagi } \\
\text { auditee dalam penyelesaian permasalahan organisasi } \\
\text { auditee. }\end{array}$ & 3,91 & 78,2 & Baik \\
\hline 15 & $\begin{array}{l}\text { Personil internal audit mempunyai kualifikasi } \\
\text { profesional yang tinggi dan mendapat pelatihan yang } \\
\text { memadai. }\end{array}$ & 4,12 & 82,4 & $\begin{array}{l}\text { Sangat } \\
\text { Baik }\end{array}$ \\
\hline 16 & $\begin{array}{l}\text { Entitas internal audit adalah sumber data dan } \\
\text { informasi yang bernilai bagi pengambil keputusan di } \\
\text { Kementerian/Lembaga/ Pemerintah Daerah. }\end{array}$ & 4,21 & 84,1 & $\begin{array}{l}\text { Sangat } \\
\text { Baik }\end{array}$ \\
\hline 17 & $\begin{array}{l}\text { Informasi yang disediakan oleh entitas internal audit } \\
\text { penting untuk operasional } \\
\text { Kementerian/Lembaga/Pemerintah Daerah }\end{array}$ & 4,15 & 82,9 & $\begin{array}{l}\text { Sangat } \\
\text { Baik }\end{array}$ \\
\hline 18 & $\begin{array}{l}\text { Hasil pekerjaan internal audit memberikan manfaat } \\
\text { yang lebih tinggi dibanding kos yang dikorbankan }\end{array}$ & 3,68 & 73,5 & Baik \\
\hline 19 & $\begin{array}{l}\text { Investasi untuk pelatihan dan pengembangan personil } \\
\text { internal audit dilakukan secara konsisten dalam } \\
\text { rangka menjadikan internal audit sebagai sumber } \\
\text { SDM untuk proses regenerasi posisi manajerial } \\
\text { dalam Kementerian/Lembaga/ Pemerintah Daerah. }\end{array}$ & 4,26 & 85,3 & $\begin{array}{l}\text { Sangat } \\
\text { Baik }\end{array}$ \\
\hline 20 & $\begin{array}{l}\text { Pekerjaan internal audit dilakukan dengan teknologi } \\
\text { modern yang menggunakan data berbasis komputer } \\
\text { dan software audit internal khusus. }\end{array}$ & 4,03 & 80,6 & $\begin{array}{l}\text { Sangat } \\
\text { Baik }\end{array}$ \\
\hline 21 & $\begin{array}{l}\text { Semua fungsi audit yang telah disetujui dalam } \\
\text { rencana audit dilakukan secara keseluruhan. }\end{array}$ & 4,12 & 82,4 & $\begin{array}{l}\text { Sangat } \\
\text { Baik }\end{array}$ \\
\hline 22 & $\begin{array}{l}\text { Terdapat permintaan untuk entitas internal audit } \\
\text { untuk mengaudit masalah selain yang telah } \\
\text { ditentukan dan disetujui dalam perencanaan audit } \\
\text { tahunan. }\end{array}$ & 3,88 & 77,6 & Baik \\
\hline 23 & $\begin{array}{l}\text { Jumlah keluhan tentang entitas internal audit sangat } \\
\text { rendah. }\end{array}$ & 2,73 & 54,7 & $\begin{array}{l}\text { Cukup } \\
\text { Baik }\end{array}$ \\
\hline 24 & $\begin{array}{l}\text { Audite menunjukkan tingkat kepuasan yang tinggi } \\
\text { dengan pekerjaan entitas internal audit. }\end{array}$ & 3,65 & 72,9 & Baik \\
\hline 25 & $\begin{array}{l}\text { Waktu tunggu di antara penyelesaian audit dan } \\
\text { penyampaian laporan audit terlalu panjang }\end{array}$ & 3,03 & 60,6 & Baik \\
\hline 26 & $\begin{array}{l}\text { Temuan internal audit signifikan/material bagi } \\
\text { Kementerian/Lembaga/ Pemerintah Daerah. }\end{array}$ & 3,97 & 79,4 & Baik \\
\hline
\end{tabular}




\begin{tabular}{|l|l|l|l|l|}
\hline No & Item Pernyataan & Rerata & $\begin{array}{l}\text { TCR } \\
(\mathbf{\%})\end{array}$ & Kategori \\
\hline 27 & $\begin{array}{l}\text { Temuan internal audit selalu didasarkan pada } \\
\text { dokumen dan data yang dapat dipercaya. }\end{array}$ & 4,12 & 82,4 & $\begin{array}{l}\text { Sangat } \\
\text { Baik }\end{array}$ \\
\hline 28 & $\begin{array}{l}\text { Rekomendasi dari entitas internal audit dapat dengan } \\
\text { mudah diimplementasikan. }\end{array}$ & 4.35 & 87,1 & $\begin{array}{l}\text { Sangat } \\
\text { Baik }\end{array}$ \\
\hline 29 & $\begin{array}{l}\text { Rekomendasi dari lembaga audit internal } \\
\text { memberikan solusi praktis, memperhitungkan biaya- } \\
\text { manfaat untuk memperbaiki permasalahan yang } \\
\text { ditemukan. }\end{array}$ & $\begin{array}{l}\text { Sangat } \\
\text { Baik }\end{array}$ \\
\hline 30 & $\begin{array}{l}\text { Seluruh rekomendasi entitas internal audit } \\
\text { diimplementasikan oleh auditee. }\end{array}$ & $\begin{array}{l}\text { L,12 } \\
\text { persisten) dan akurat. }\end{array}$ & 82,4 & $\begin{array}{l}\text { Sangat } \\
\text { Baik }\end{array}$ \\
\hline 32 & $\begin{array}{l}\text { Laporan internal audit disajikan secara jelas dan } \\
\text { mudah dipahami. }\end{array}$ & 4,06 & 81,2 & $\begin{array}{l}\text { Sangat } \\
\text { Baik }\end{array}$ \\
\hline 33 & $\begin{array}{l}\text { Laporan internal audit meliputi pendahuluan, tujuan, } \\
\text { subyek, kesimpulan dan rekomendasi. }\end{array}$ & 4,53 & 90,6 & $\begin{array}{l}\text { Sangat } \\
\text { Baik }\end{array}$ \\
\hline 34 & $\begin{array}{l}\text { Laporan internal audit profesional dan berkualitas } \\
\text { tinggi. }\end{array}$ & 3,97 & 79,4 & Baik \\
\hline 35 & $\begin{array}{l}\text { Proses pengambilan keputusan manajemen sangat } \\
\text { dipengaruhi oleh laporan dan temuan entitas internal } \\
\text { audit. }\end{array}$ & $\begin{array}{l}\text { Entitas internal audit berkontribusi melebihi kos yang } \\
\text { dikorbankan oleh Kementerian/Lembaga/ } \\
\text { Pemerintah Daerah }\end{array}$ & $\begin{array}{l}\text { Rata-Rata Variabel } \\
\text { Baik }\end{array}$ \\
\hline 36 Baik \\
\hline
\end{tabular}

Berdasarkan tabel distribusi frekuensi variabel efektifitas fungsi audit internal dapat dilihat bahwa tingkat capaian responden tertinggi berada pada pernyataan no 33, yaitu 90,6\% dengan kategori sangat baik. Hal ini menunjukkan bahwa auditor internal inspektorat provinsi Sumatera Barat berpendapat bahwa auditor internal yang dapat memberikan evaluasi, penilaian, dan rekomendasi secara tepat dalam menjalankan tugas dan kewajibannya. Sedangkan untuk tingkat capaian responden terendah berada pada pernyataan no 23 , yaitu sebesar $54,7 \%$ dengan kategori cukup baik. Hal ini menunjukkan adanya temuan-temuan yang tidak ditindaklanjuti atau rekomendasi yang belum ditindaklanjuti oleh organisasi yang diperiksa.

Berdasarkan penjelasan diatas dapat dilihat bahwa auditor internal di inspektorat provinsi Sumatera Barat dengan 34 responden yang diteliti terlihat bahwa rata-rata tingkat capaian responden pada variabel efektifitas fungsi audit internal adalah sebesar $80 \%$ dengan kategori sangat baik. Hal ini menunjukkan bahwa responden auditor internal pada inspektorat provinsi Sumatera Barat menilai efektifitas fungsi audit internal dapat dikatakan sangat baik.

\section{b) Independensi}

Variabel independensi yang diteliti dalam penelitian ini berkaitan dengan hubungan kerja didalam entitas internal audit, hubungan kerja antar sesame auditor dan hubungan kerja auditor dengan manajemen. Aspek penelitian ini tersebar dalam 9 item pernyataan pada kuesioner dapat dilihat dalam tabel 3. berikut. 
Tabel 3.

Distribusi fekuensi Variabel Independensi

\begin{tabular}{|c|c|c|c|c|}
\hline No & Item Pernyataan & Rerata & $\begin{array}{l}\text { TCR } \\
(\%)\end{array}$ & Kategori \\
\hline 1 & $\begin{array}{l}\text { Saya memiliki hubungan kerja langsung dan teratur } \\
\text { dengan penanggungjawab entitas internal audit }\end{array}$ & 3,68 & 73,5 & Baik \\
\hline 2 & $\begin{array}{l}\text { Saya memiliki hubungan kerja langsung dan teratur } \\
\text { dengan penanggungjawab dan pelaksana } \\
\text { Kementerian/Lembaga/ Pemerintah daerah }\end{array}$ & 4,47 & 89,4 & $\begin{array}{l}\text { Sangat } \\
\text { Baik }\end{array}$ \\
\hline 3 & $\begin{array}{l}\text { Hasil pekerjaan auditor internal membutuhkan } \\
\text { persetujuan ketua tim, supervisor, dan } \\
\text { penanggungjawab internal audit }\end{array}$ & 3,85 & 77,1 & Baik \\
\hline 4 & $\begin{array}{l}\text { Seluruh data Kementerian/Lembaga/Pemerintah } \\
\text { Daerah dapat diakses dan diperiksa oleh auditor } \\
\text { internal }\end{array}$ & 4,41 & 88,2 & $\begin{array}{l}\text { Sangat } \\
\text { Baik }\end{array}$ \\
\hline 5 & $\begin{array}{l}\text { Proposal anggaran terinci dan informasi tentang staf } \\
\text { termasuk di dalam rencana kerja tahunan entitas } \\
\text { internal audit }\end{array}$ & 4,09 & 81,8 & $\begin{array}{l}\text { Sangat } \\
\text { Baik }\end{array}$ \\
\hline 6 & $\begin{array}{l}\text { Terdapat rotasi staf internal audit untuk memperoleh } \\
\text { kemampuan dalam bidang penugasan internal audit } \\
\text { yang beragam }\end{array}$ & 4,09 & 81,8 & $\begin{array}{l}\text { Sangat } \\
\text { Baik }\end{array}$ \\
\hline 7 & $\begin{array}{l}\text { Entitas internal audit juga melakukan aktivitas yang } \\
\text { beragam bahkan termasuk aktivitas yang tidak } \\
\text { secara langsung berkaitan dengan } \\
\text { tanggungjawabnya }\end{array}$ & 4,59 & 91,8 & $\begin{array}{l}\text { Sangat } \\
\text { Baik }\end{array}$ \\
\hline 8 & $\begin{array}{l}\text { Entitas internal audit dapat berperan dalam design } \\
\text { sistem dan pengembangan prosedur operasional di } \\
\text { Kementerian/Lembaga/ Pemerintah Daerah }\end{array}$ & 4,06 & 81,2 & $\begin{array}{l}\text { Sangat } \\
\text { Baik }\end{array}$ \\
\hline \multirow[t]{2}{*}{9} & $\begin{array}{l}\text { Seluruh kegiatan operasional internal audit } \\
\text { dilakukan secara independen, dapat mengaudit } \\
\text { persoalan apapun yang membutuhkan pemeriksaan, } \\
\text { dan dapat mengakses informasi penting apapun } \\
\text { bahkan jika itu dirahasiakan }\end{array}$ & 3,76 & 75,3 & Baik \\
\hline & Rata-Rata Variabel & 4,11 & 82,2 & $\begin{array}{l}\text { Sangat } \\
\text { Baik }\end{array}$ \\
\hline
\end{tabular}

Berdasarkan tabel distribusi frekuensi variabel independensi dapat dilihat bahwa tingkat capaian responden tertinggi berada pada pernyataan no 7, yaitu sebesar $91,8 \%$ dengan kategori sangat baik. Hal ini menunjukkan bahwa seorang auditor harus bersikap bebas, jujur, dan objektif dalam penugasan audit. Sedangkan tingkat capaian responden terendah berada pada pernyataan no 1 yaitu sebasar 73,5\% degan kategori baik. Hal ini menunjukkan bahwa seorang auditor memeriksa dalam keadaan bebas tanpa ada intervensi dari pihak manapun.

Berdasarkan penjelasan diatas dapat dilihat bahwa auditor internal di inpektorat provinsi Sumatera Barat dengan 34 responden yang diteliti dapat dilihat bahws rata-rata tingkat capaian responden pada variabel independensi adalah sebesar 82,2\% dengan kategori sangat baik. Hal ini menunjukkan responden auditor internal di inspektorat provinsi Sumatera Barat menilai variabel independensi dapat dikatakan sangat baik. 


\section{c) Keahlian Profeional}

Variabel yang diteliti dalam penelitian ini berkaitan dengan pendidikan dan pelatihan yang diikuti oleh auditor untuk menunjang profesionalisme auditor dalam menjalankan tugas, Aspek penelitian ini tersebar dalam 6 pernyataan pada kuesioner dapat dilihat pada tabel 4 . berikut.

Tabel 4.

Distribusi Frekuensi Variabel Keahlian Profesional

\begin{tabular}{|c|c|c|c|c|}
\hline No & Item Pernyataan & Rerata & $\begin{array}{l}\text { TCR } \\
(\%)\end{array}$ & Kategori \\
\hline 1 & $\begin{array}{l}\text { Instansi saudara membolehkan pegawainya untuk turut } \\
\text { serta dalam pelatihan untuk meningkatkan kompetensi } \\
\text { audit }\end{array}$ & 4,44 & 88,8 & $\begin{array}{l}\text { Sangat } \\
\text { Baik }\end{array}$ \\
\hline 2 & $\begin{array}{l}\text { Instansi saudara membolehkan pegawainya untuk turut } \\
\text { serta dalam berbagai kegiatan seminar program } \\
\text { pengembangan dalam rangka meningkatkan } \\
\text { kemampuan audit }\end{array}$ & 4,53 & 90,6 & $\begin{array}{l}\text { Sangat } \\
\text { Baik }\end{array}$ \\
\hline 3 & $\begin{array}{l}\text { Saudara mendapatkan pendidikan audit yang tepat dan } \\
\text { relevan untuk mengaudit seluruh system keuangan } \\
\text { lembaga (inspektorat) sesuai dengan lingkup yang telah } \\
\text { ditentukan dalam peraturan perundang-undangan }\end{array}$ & 4,38 & 87,6 & $\begin{array}{l}\text { Sangat } \\
\text { Baik }\end{array}$ \\
\hline 4 & $\begin{array}{l}\text { Saudara mendapatkan pendidikan audit yang tepat dan } \\
\text { relevan untuk mengaudit seluruh sistem operasional } \\
\text { lembaga (inspektorat) sesuai dengan lingkup yang telah } \\
\text { ditentukan dalam peraturan perundang-undangan }\end{array}$ & 4,53 & 90,6 & $\begin{array}{l}\text { Sangat } \\
\text { Baik }\end{array}$ \\
\hline 5 & $\begin{array}{l}\text { Saudara mendapatkan pendidikan audit yang tepat dan } \\
\text { relevan untuk mengaudit seluruh sistem logistic } \\
\text { lembaga (inspektorat) sesuai dengan lingkup yang telah } \\
\text { ditentukan dalam peraturan perundang-undangan }\end{array}$ & 4,38 & 87,6 & $\begin{array}{l}\text { Sangat } \\
\text { Baik }\end{array}$ \\
\hline \multirow[t]{2}{*}{6} & $\begin{array}{l}\text { Saudara mendapatkan pendidikan audit yang tepat dan } \\
\text { relevan untuk mengaudit seluruh sistem } \\
\text { terkomputerisasi lembaga (inspektorat) sesuai dengan } \\
\text { lingkup yang telah ditentukan dalam peraturan } \\
\text { perundang-undangan }\end{array}$ & 4,24 & 84,7 & $\begin{array}{l}\text { Sangat } \\
\text { Baik }\end{array}$ \\
\hline & Rata-Rata Variabel & 4,42 & $\mathbf{8 8 , 3}$ & $\begin{array}{l}\text { Sangat } \\
\text { Baik }\end{array}$ \\
\hline
\end{tabular}

Berdasarkan tabel distribusi frekuensi variabel keahlian professional dapat dilihat bahwa tingkat capaian responden tertinggi berada pernyataan no 2, yaitu sebesar 90,6\% dengan kategori sangat baik dan tingkat capaian responden terendah berada pada pernyataan no 6 , yaitu sebesar $84,7 \%$ dengan kategori sangat baik. Hal ini menunjukkan bahwa seorang auditor yang kompeten, memiliki pemahaman dan berpengalaman akan menunjang profesionalisme dalam menjalankan tugasnya.

Berdasarkan penjelasan diatas dapat dilihat bahwa auditor internal di inspektorat provinsi Sumatera Barat dengan 34 responden yang diteliti dapat dilihat rata-rata tingkat capaian responden variabel keahlian professional adalah sebesar $88,3 \%$ dengan kategori sangat baik. Hal ini menunjukkan bahwa responden auditor internal di inspektorat provinsi Sumatera Barat menilai keahlian professional dapat dikatakan sangat baik. 


\section{d) Dukungan Manajemen}

Variabel yang diteliti dalam penelitian ini berkaitan dengan dukungan materil dan moril. Aspek penelitian ini tersebal dalam 5 item pernyataan pada kuesioner dapat dilihat pada tabel 5. berikut.

\section{Tabel 5.}

Distribusi Frekuensi Variabel Dukungan Manajemen

\begin{tabular}{|l|l|l|l|l|}
\hline No & Item Pernyataan & Rerata & $\begin{array}{l}\text { TCR } \\
(\boldsymbol{\%})\end{array}$ & Kategori \\
\hline 1 & $\begin{array}{l}\text { Instansi saudara menyediakan dukungan seperti yang } \\
\text { saudara harapkan }\end{array}$ & 4,03 & 80,6 & $\begin{array}{l}\text { Sangat } \\
\text { Baik }\end{array}$ \\
\hline 2 & $\begin{array}{l}\text { Jumlah auditor internal memadai untuk menyelesaikan } \\
\text { sejumlah pekerjaan audit yang direncanakan dan } \\
\text { diselesaikan dalam waktu yang cukup }\end{array}$ & 4,65 & 92,9 & $\begin{array}{l}\text { Sangat } \\
\text { Baik }\end{array}$ \\
\hline 3 & $\begin{array}{l}\text { Instansi saudara menyediakan dukungan dan dorongan } \\
\text { yang tinggi untuk pelatihan dan pengembangan staf } \\
\text { auditor internal }\end{array}$ & $\begin{array}{l}\text { Instansi saudara mempunyai kepedulian yang tinggi } \\
\text { terhadap kebutuhan auditor internal, seperti ditunjukkan } \\
\text { dengan persetujuan besaran anggaran yang cukup untuk } \\
\text { pelaksanaan proses audit }\end{array}$ & 91,8 & $\begin{array}{l}\text { Sangat } \\
\text { Baik }\end{array}$ \\
\hline 5 & $\begin{array}{l}\text { Instansi saudara memberikan alokasi dana yang lancar } \\
\text { untuk pelaksanaan proses audit }\end{array}$ & 4,09 & 81,8 & $\begin{array}{l}\text { Sangat } \\
\text { Baik }\end{array}$ \\
\hline Rata-Rata Variabel & $\mathbf{4 , 3 4}$ & $\mathbf{8 6 , 8}$ & $\begin{array}{l}\text { Sangat } \\
\text { baik }\end{array}$ \\
\hline
\end{tabular}

Berdasarkan tabel distribusi frekuensi variabel dukungan manajemen dapat dilihat bahwa tingkat capaian responden tertinggi berada pada pernyataan no 2, yaitu sebesar $92,9 \%$ dengan kategori sangat baik dan tingkat capaian responden terendah berada pada pernyataan no 1, yaitu sebesar 80,6\% dengan kategori sangat baik. Hal ini menunjukkan bahwa dengan adanya dukungan yang cukup seorang auditor akan menjalankan tugasnya dengan baik.

Berdasarkan penjelasan diatas dapat dilihat bahwa auditor intenal di inspektorat provinsi Sumatera Barat dengan 34 responden yang diteliti dapat dilihat rata-rata tingkat capaian responden variabel dukungan manejemen adalah sebesar $86,8 \%$ dengan kategori sangat baik. Hal ini menunjukkan auditor internal di inspektorat provinsi Sumatera Barat menilai dukungan manajemen dapat dikatakan sangat baik.

\section{Hasil Uji Asumsi Klasik}

Sebelum data diolah dengan regresi berganda maka dilakukan uji asumsi klasik untuk memperoleh kayakinan bahwa data diperoleh beserta variabel penelitian layak untuk diolah lebih lanjut. Uji asumsi klasik dalam penelitian ini terdiri dari beberapa uji, diantaranya adalah :

\section{Uji Normalitas}

Pengujian normalitasdata dilakukan setelah pendistribusian dan pengelompokan data menggunakan bantuan softwere SPSS versi 22. Tujuan daru uji normalitas ini adalah untuk menguji apakah data terdistribusi secara normal atau tidak. Pengujian normalitas dalam penelitian ini dilakukan dengan menggunakan one sample kolmogrof-smirnov test dengan taraf signifikan 5\%. Penentuan test kenormalan data, dilakukan dengan cara membandingkan nilai Signifikan (Sig) dengan Alpa $(\alpha)$ sebesar 0,05. Data dikatakan berdistribusi normal jika Sig > 
0,05 sedangkan data dikatakan berdistribusi tidak normal jika Sig < 0,05. Dari hasil pengolahan data SPSS didapat bahwa nilai Sig variabel sebesar 0,200 lebih besar dari 0,05 maka berdasarkan hasil tersebut dapat dinyatakan data yang digunakan dalam penelitian ini telah terdistribusi normal dan bisa dilanjutkan diteliti lebih lanjut.

\section{Uji Heterokedastisitas}

Setelah dilakukan uji normalitas selanjutnya dilakukan uji heterokedastisitas. Uji heterokedastisitas bertujuan untuk menguji apakah dalam sebuah model regresi terjadi ketidaksamaan varians dan residual atas pengamatan ke pengamatan yang lain. Pengujian heterokedastisitas menggunakan metode Gletser. Penentuan heterokedastisitas data dilakukan dengan cara melihat nilai Signifikan (Sig) dengan Alpha $(\alpha)$ sebesar 5\%. Data dapat dikatakan tidak terdapat heterokedastisitas apabila nilai Sig > 0,05. Hasil uji heterokedastisitas data diketahui bahwa nilai Signifikan (Sig) data independensi (X1) sebesar 1,000, keahlian professional (X2) sebesar 1,000, dan dukungan manajemen (X3) sebesar 1,000 dapat disimpulkan tidak terdapat heteroskedastisitas karena nilai Sig > 0,05.

\section{Uji Multikolinearitas}

Untuk menguji adanya multikolinearitas dapat dilihat melalui Variance Inflantion Factor (VIF) $<10$ tolerance > 0,1. Maka dapat dikatakan tidak terkena atau bebas dari gejala multikolinearitas. Berdasarkan uji multikolinearitas dapat dilihat bahwa variabel independen (X1), dengan VIF 1,224, variabel keahlian professional (X2), dengan VIF 1,197, variabel dukungan manajemen (X3) dengan VIF 1,251. Pada variabel independen (X1) dengan nilai tolerance 0,817 , variabel keahlian professional (X2) dengan nilai tolerance 0,836 , variabel dukungan manajemen (X3) dengan nilai tolerance 0,799. Dari hasil uji multikolinearitas, dapat dikatakan bahwa tidak dapat kolerasi variabel-variabel bebas antara satu dengan lainnya atau variabel independent pada penelitian ini bebas multikolinearitas.

\section{Hasil Analisis Regresi}

Teknik analisis berganda digunakan untuk mengetahui besarnya perubahan variabel terikat yang disebabkan oleh perubahan yang terjadi pada variabel bebas. Kegiatan perhitungan statistic menggunakan softwere SPSS 22. Dengan bantuan program SPSS, koefisien yang diperoleh dari hasil pengolahan data tentang independensi, keahlian professional, dukungan manajemen dapat diketahui bahwa nilai sig sebesar 0,001 < 0,05 sehingga model regresi yang di pakai dapat digunakan.

\section{A. Uji Model}

\section{Uji Koefisien Determinasi $\left(\mathbf{R}^{2}\right)$}

Nilai Adjusted $R$ Square menunjukkan seberapa besar pengaruh variabel independen yang digunakan dalam penelitian mampu menjelaskan variabilitas total dari variabel dependen. Pada penelitian ini digunkan Adjusted $R$ Square karenz variabel bebas yang digunakan pada penelitian ini lebih dari satu. Semakin meningkat atau banyak variabel X, Adjuster $R$ Square akan meningkat dengan peningkatan yang lebih kecil disbanding dengan R2 dapat diketahui bahwa nilai Adjusted $R$ Square adalah 0,662. Hal ini berarti besar kontribusi antara independensi, keahlian professional, dan dukungan manajemen terhadap efektifitas fungsi audit internal adalah 0,662 atau $66,2 \%$. Sedangkan 0,338 atau 33,8\% disumbangkan oleh faktor lain yang tidak diteliti dalam penelitian ini. 


\section{Uji F (F-Test)}

Uji statisti F pada dasarnya menunjukkan apakah semua variabel bebas dimasukkan dalam model mempunyai pengaruh secara bersama-sama terhadap variabel terikat, penghitungan statistik dibantu dengan softwere SPSS 22 yang dapat dilihat bahwa independensi, keahlian profsional, dan dukungan manajemen terhadap efektifitas fungsi audit internal dapat dilakukan pengujian terhadap hipotesis yang diajukan untuk menguji hipotesis ini,maka dilakukan uji $\mathrm{F}$ dengan membandingkan nilai $F_{\text {hitung }}$ dengan $F_{\text {tabel }}$ pada level signifikansi 0,05. Hasil pengolahan statistik analisis regresi menunjukkan $F_{\text {hitung }}>F_{\text {tabel }}$ dimana nilai F 22,533 > 1,69 pada level Sig 0,000 < 0,05 , hal ini menunjukkan bahwa variabel independensi, keahlian professional dan dukungan manajemen secara bersama-sama berpengaruh secara signifikan terhadap efektifitas fungsi audit internal pada inspektorat provinsi Sumatera Barat .

\section{B. Uji Hipotesis}

Pengujian hipotesis dalam penelitian ini dilakukan dengan memmbandingkan antara (a) nilai Sig dengan dengan $\alpha$ yang diajukan sebesar $95 \%$ atau 0,05 dan (b) membandingkan nilai $\mathrm{T}$ hitung dengan $\mathrm{T}$ tabel. Hipotesis diterima jika $\mathrm{T}$ hitung $>\mathrm{T}$ tabel dan $\mathrm{Sig}<0,05$.

Hipotesis pertama adalah independensi auditor berpengaruh signifikan positif terhadap efektifitas fungsi audit internal. Hasil analisis data menunjukan bahwa nilai T tabel pada $\alpha=0,05$ adalah 1,70, nilai $\mathrm{T}$ hitung untuk variabel independensi adalah 2,466. Dengan demikian dapat diketahui bahwa T hitung $>\mathrm{T}$ tabel yaitu 2,466 $>1,70(0,02<0,05)$ dengan nilai $\beta 0,602$. Hal ini menunjukkan independensi auditor berpengaruh signifikan positif tehadap efektifitas audit internal, dengan demikian hipotesis pertama diterima. Hipotesis kedua adalah keahlian professional berpengaruh signifikan positif terhadap efektifitas audit internal. Hasil analisis data menunjukan bahwa nilai $\mathrm{T}$ tabel pada $\alpha=0,05$ adalah 1,70 , nilai $\mathrm{T}$ hitung untuk variabel keahlian professional adalah 3,895. Dengan demikian dapat diketahui bahwa $\mathrm{T}$ hitung $>\mathrm{T}$ tabel yaitu 3,895 $>1,70(\operatorname{Sig} 0,01<0,05)$ dengan nilai $\beta$ 0,714. Hal ini menunjukkan keahlian professional berpengaruh signifikan positif terhadap efektifitas audit internal, dengan demikian hipotesis kedua diterima. Hipotesis ketiga adalah dukungan manajemen berpengaruh signifikan positif terhadap efektifitas audit internal. Hasil analisis data menunjukan bahwa nilai $\mathrm{T}$ tabel pada $\alpha=0,05$ adalah 1,70 , nilai $\mathrm{T}$ hitung untuk variabel dukungan manajemen adalah 5,889. Dengan demikian dapat diketahui bahwa T hitung $>\mathrm{T}$ tabel yaitu 5,889 $>1,70($ Sig $0,00<0,05)$ dengan nilai $\beta 0,921$. Hal ini menunjukkan dukungan manajemen berpengaruh signifikan positif terhadap efektifitas audit internal, dengan demikian hipotesi ketiga diterima.

\section{Pembahasan}

\section{Pengaruh Independensi Terhadap Efektifitas Fungsi Audit Internal Inspektorat Provinsi Sumatera Barat}

Hasil analisis data penilitian menunjukkan bahwa independensi (X1) bepengaruh positif terhadap efektifitas fungsi audit internal (Y) inspektorat provinsi Sumatera Barat. Hal ini dibuktikan oleh hasil uji regresi yang menunjukkan nilai signifikan lebih kecil dari level of signifikan $(0,02<$ 0,05 ) yang berarti bahwa variabel $\mathrm{X} 1$ berpengaruh signifikan positif terhadap variabel $\mathrm{Y}$ dan nilai koefisien regresi menunjukkan arah hubungan positif sebesar 2,466 sehingga H1 diterima.

Hal ini menggambarkan bahwa auditor yang melakukan audit sesuai dengan standar audit internal (AAIPI, 2014) dan tidak memiliki kepentingan ataupun hubungan (baik hubungan kekeluargaan maupun hubungan keuangan) dengan instansi yang di audit, sehingga auditor memiliki kebebasan dalam menjalankan tugasnya. Independensi yang dimiliki auditor dapat 
meningkatkan fungsi efektiivitas audit internal, maka hasil audit yang dihasilkan dapat memberi nilai tambah dan rekomendasi perbaikan untuk instansi yang diaudit.

Analisis ini sejalan dengan penelitian yang dilakukan Cohen (2010) dan Mihret et al. (2010) yang menyatakan bahwa independensi berpengaruh terhadap efektifitas audit internal. Hasil penelitian Donza et al. (2015) juga mengatakan bahwa independensi auditor internal memberikan pengaruh positif terhadap kemampuan audit internal dalam memberikan nilai tambah bagi organisasi. Selain itu hasil peneliian Arles et al. (2017) juga menggambarkan bahwa faktor independensi berpengaruh positif terhadap efektifitas audit internal. Auditor yang independen dapat memberikan rekomendasi perbaikan unntuk instansi yang diaudit, apabila rekomendasi tersebut dilaksanakan oleh instansi yang audit maka dapat dikatakan bahwa auditor audit internal telah efektif dalam menjalankan tugas. Selain dapat memberi nilai tambah dan rekomendasi perbaikan untuk instansi yang diaudit, independensi yang dimiliki seorang auditor juga dapat memberikan hasil yang sesuai dengan keadaan dilapangan sehingga hasil tersebut dapat dipercayai dan diterima oleh masyarakat.

\section{Pengaruh Keahlian Professional Terhadap Efektifitas Fungsi Audit Internal Inspektorat Provinsi Sumatera Barat}

Hasil analisis data penelitian menunjukkanbahwa keahlian profesional berpengaruh signifikan positif terhadap efektifitas fungsi audit internal inspektorat provinsi Sumatera Barat. Hasil penelitian menunjukkan bahwa keahlian professional (X2) berpengaruh positif terhadap efektifitas fungsi audit internal (Y) inspektorat provinsi Sumatera Barat. Hal ini dibuktikan oleh hasil uji regresi yang menunjukkan nilai signifikan lebih kecil dari level of signifikan $(0,01<$ $0,05)$ yang berarti variabel $\mathrm{X} 1$ berpengaruh signifikan terhadap $\mathrm{Y}$ dan nilai koefisien regresi menunjukkan arah hubungaan 3,895 sehingga $\mathrm{H} 2$ diterima.

Analisis ini menunjukan bahwa pendidikan serta pelatihan yang ditempuh oleh seorang auditor atau yang dikenal dengan keahlian profesional yang dimiliki auditor dapat memberikan pengaruh terhadap efektifitas fungsi audit yang dilakukannya. Hal ini sejalan dengan penelitian yang dilakukan Akram et al. (2015), Al-Twaijry et al. (2003), Arena dan Azzone (2009) yang menunjukan bahwa keahlian profesional yang dimiliki seorang auditor berpengaruh terhadap efektifitas audit internal yang dilakukan.

Seorang auditor yang memiliki keahlian profesional yang memadai akan melakukan audit dengan benar dan tepat sesuai dengn prosedur audit yang semestinya sehingga audit yang dilaksanakan diusahakan agar sealau efektif dan dapat meningkatkan efektifitas audit internal. Selain dapat meningkatkan efektivitas audit internal, keahlihan profesional yang sesuai dengan standar audit internal AAIPI juga dapat mendukung auditor dalam menjalankan tugas dan tanggungjawabnya secara efektif, maka hasil audit yang diperoleh akan lebih baik dan efektif. Sehingga hasil audit tersebut dapat ditindaklanjuti oleh instansi yang diaudit, apabila hasil tersebut memberikan dampak perbaikan bagi instansi yang diaudit maka dapat dikatakan bahwa audit internal yang dilakukan telah efektif.

\section{Pengaruh Dukungan Manajemen Terhadap Efektifita Fungsi Audit Internal Inspekrorat Provinsi Sumatera Barat}

Hasil analisis data penelitian menunjukkan bahwa dukungan manajemen berpengaruh signifikan positif terhadap efektifitas fungsi audit intenal inspektorat provinsi Sumatera Barat. Hasil penelitian menunjukkan bahwa dukungan manajemen (X3) berpengaruh positif terhadap efektifitas fungsi audit internal (Y) inspektorat provinsi Sumatera Barat. Hal ini dibuktikan oleh 
hasil uji regresi yang menunjukkan nilai signifikan lebih kecil dari level of signifikan $(0,00<$ $0,05)$ yang berarti variabek X3 berpengaruh signifikan positif terhadap (Y) dan nilai koefisien regresi menunjukkan arah hubungan positif sebesar 5,885 sehingga $\mathrm{H} 3$ diterima.

Analisis ini menunjukan bahwa adanya dukungan menajemen yang diberikan kepada auditor baik berupa sarana prasarana maupun pendanaan dapat mendukung efektifitas audit yang dilakukan, karena dengan adanya sarana prasarana serta pendanaan yang memadai dapat memberika keleluasaan kepada auditor dalam menjalankan tugas dan tanggungjawabnya. Hal ini sejalan dengan penelitian yang dilakukan oleh Akram et al. (2015), Tri et al (2016), dan Arles et al. (2017) menunjukan bahwa dukungan dari manajemen yang diberikan kepada auditor berpengaruh terhadap efektifitas audit internal yang dihasilkan auditor tersebut.

Selain sarana prasarana dan pendanaan yang diberikan kepada auditor, dukungan manajemen juga dapat berupa suatu program yang dirancang untuk mendukung auditor dalam menjalankan tugasnya serta mengembangkan dan menjamin kualitas audit yang dilakukan. Dukungn manajemen ini sangat penting dalam audit internal, sebab audit internal tidak akan berjalan dengan baik apabila tidak ada dukungan dari manejemen. Dukungan menejemen ini juga dapat memberikan motivasi kepada auditor untuk menjalankan tugasnya sesuai dengan standar audit internal AAIPI, sehingga dapat menyumbangkan hasil audit yang bisa memberikan nilai dan rekomendasi kepada instansi yang di audit.

\section{SIMPULAN, KETERBATASAN DAN SARAN Simpulan}

Berdasarkan hasil penelitian dan pembahasan yang telah dipaparkan maka dapat ditarik kesimpulan sebagai berikut: (1) independensi berpengaruh positif terhadap efektivitas audit internal inspektorak provinsi Sumatera Barat, (2) keahlian profesional berpengaruh positif terhadap efektivitas audit internal inspektorak provinsi Sumatera Barat, (3) dukungan manajemen berpengaruh positif terhadap efektivitas audit internal inspektorak provinsi Sumatera Barat

\section{Keterbatasan}

Meskipun peneliti telah berusaha merancang dan mengembangkan penelitian sedemikian rupa, namun masih terdapat beberapa keterbatasan dalam penelitian ini yaitu: (1) data pada penelitian ini dijaring menggunakan kuesioner tanpa dilengkapi dengan wawancara atau pertanyaan lisan dan peneliti tidak mampu mengontrol secara ketat seluruh pernyataan responden yang mengisi kuesioner penelitian untuk mengumpulkan data penelitian terhadap tingkat kejujuran responden sehingga terkadang jawaban yang diberikan oleh responden tidak menunjukan keadaan sesungguhnya. (2) walaupun dalam pengisian angket sudah diupayakan secara teliti dan hati-hati, tentunya hal tersebut juga tidak lepas dari kemungkinan adanya responden yang mengisi kuisioner dengan tidak serius dan asal-asalan.

\section{Saran}

Berdasarkan pembahasan dan kesimpulan di atas, maka penulis memberikan saran sebagai berikut: (1) pada penelitian ini hanya meneliti pengaruh variabel independensi, keahlian profesional serta dukungan manajemen terhadap efektivitas fungsi audit internal, maka untuk penelitian yang akan datang sebaiknya meneliti variabel-variabel lain yang mempengaruhi efektivitas fungsi audit internal. (2) penelitian selanjutnya sebaiknya menggunakan sampel penelitian yang lebih luas, karena pada penelitian ini lingkup sampel masih sempit yaitu hanya di 
inspektorat provinsi Sumatera Barat saja. (3) penelitian berikutnya sebaiknya tidak hanya menggunakan kuesioner saja, ada baiknya juga melakukan wawancara secara langsung kepada responden atau menggunakan kuesioner eksperimen untuk meminimalisasi kelemahan internal validity

\section{DAFTAR PUSTAKA}

AAIPI. (2014). Keputusan Nomor: KEP-005/AAIPI/DPN/2014 Tentang Pemberlakuan Kode Etik Auditor Intern Pemerintah Indonesia, Standar Audit Intern Pemerintah Indonesia, dan Pedoman Telaah Sejawat AuditorIntern Pemerintah Indonesia.

AAIPI. (2014). Standar Audit Intern Pemerintah Indonesia.

Alzeban, A. (2014). Factors Affecting the Internal Audit Effectiveness: A Survey of the Saudi Public Sector. Journal of International Accounting, Auditing and Taxation. Doi:10.1016.

Al-Twaijry,A., Brierley. J.A., Gwilliam, D.R. (2003). The Development of internal audit in Saudi Arabia: An institutional theory perspective. CriPers. Account. 14: 507-531.

Anto, A. T., Sutaryo \& Prayamta. (2016). Determinasi Efektivitas Audit Internal Pemerintah di Indonesia. Simposium Nasional Akuntansi XIX.

Arena, M. \& Azzone, G. (2009). Identifying Organizational Drivers of Internal Audit Effectiveness.International Journal of Auditing. ISSN 1090-6738.

Arens, A.A. dan Loebbecke. (2008). Auditing Pendekatan Terpadu. Salemba Empat. Jakarta.

Arens, et al. (2010). Auditing and Assurance Services: An Integrated Approach.13th Edition. Pearson PrenticeHall.

Asare, Thomas. (2009). Internal Auditing in the Public Sector: Promoting Good Governance and Performance Improvement. International Journal on Governmental Financial Management, 9(1): 15-28.

Cohen, A. \& Sayag, G. (2010). The Effectiveness of Internal Auditing: An Empirical Examination of its Determinants in Israeli Organisations. Australian Accounting Review No. 54 Vol. 20 Issue 3. doi: 10.1111/j.1835-2561.2010.00092.

Coram, P., Colin, F. \& Robyn, M. (2008). Internal Audit, Alternative Internal Audit Structures and the Level of Misappropriation of Assets Fraud. Accounting and Finance, 48: 543559.

D’Silva, K. \& Jeffrey, R. (2007). Internal Auditing's International Contribution to Governance. International Journal Business Governance and Ethics, 3(2): 113-126.

Goodwin, J. \& Yeo, T., Y. (2001), 'Two factors affecting internal audit independence and objectivity: Evidence from Singapore', International Journal of Auditing, Vol. 5, No. 2, pp. 107-25.

http://acch.kpk.go.id/berdasarkan-instansitentang Penanganan TPK Berdasarkan Instansi. (Diakses April 2018).

Kode Etik dan Standar Audit APIP. (2008). Pusat Pendidikan dan Pelatihan Pengawasan Badan Pengawasan Keuangan dan Pembangunan.

Mihret, D. G. \& Yismaw, A. W. (2007). Internal audit effectiveness: an Ethiopian public sector case study. The Auditor Internal. Vol.7 No. 2;pg. 470-484.

Naufal, M., A, \& Haryanto. (2015). Determinan Efektivitas Auditor InternalPemerintah Daerah Kabupaten Se-Jawa Tengah. Diponegoro Journal Of Accounting, Vol. 4, No. 2. ISSN 2337-3806. 
Salsabila, A. \& Prayudiawan, H. (2011). Pengaruh Akuntabilitas, Pengetahuan Audit dan Gender Terhadap Kualitas Hasil Kerja Auditor Internal (Studi Empiris pada Inspektorat Wilayah Provinsi DKI Jakarta). Jurnal Telaah dan Riset Akuntansi, 4(1): 155 - 175.

Sarens, G. \& De Beelde, I. (2006), 'The relationship between internal audit and senior management: A qualitative analysis of expectations and perceptions', International Journal of Auditing, Vol. 10, No. 3, pp. 219ju09-41. 